\title{
ANALISIS FAKTOR YANG MEMPENGARUHI PENGAMBILAN KEPUTUSAN HEDGING MENGGUNAKAN INSTRUMEN DERIVATIF VALUTA ASING
}

\author{
Vincentia Ayuningtyas \\ vincentiaayuningtyas@gmail.com \\ Sabar Warsini \\ sbw.pringgo@gmail.com \\ R. Elly Mirati \\ ellymirati@yahoo.co.id
}

\begin{abstract}
This research aims at knowing factors that influences the hedging decision with foreign currency derivative instruments. This research uses the sample from non-financial companies listed on Indonesia Stock Exchange in the periode of 2013-2017. The data used in this research are secondary data taken from Indonesia Stock Exchange and the analyzed company's websites. The samples from the analyzed company are taken using the purposive sampling method. Based on the selected samples, there were 35 companies which did the hedging activity during the research period and have the data to be analyzed. The model was analysed by using logistics regression. The result of the research shows that leverage, liquidity and growth opportunity have positive and significant factore that influence hedging decision with the foreign currencies by using derivative instrument, However, financial distress has negative and significant influances while fluctuation of exchange rate did not significantly influence it.
\end{abstract}

Keywords: derivative instrument, foreign currency, foreign exchange risk, hedging, risk management

\begin{abstract}
ABSTRAK
Penelitian ini bertujuan untuk mengetahui bagaimana pengaruh pengambilan keputusan hedging menggunakan instrumen derivatif valuta asing. Penelitian ini menggunakan sampel perusahaan non keuangan yang terdaftar di BEI tahun 2013-2017. Data yang digunakan dalam penelitian ini adalah data sekunder yang diunduh dari website Bursa Efek Indonesia dan website perusahaan yang diteliti. Sampel perusahaan dipilih menggunakan metode purposive sampling. Hasil dari seleksi sampel memperoleh 35 perusahaan yang melakukan aktivitas hedging selama periode penelitian dan memiliki kelengkapan data untuk diteliti. Analisis model penelitian menggunakan analisis regresi logistik. Hasil pengujian menunjukkan ketepatan klasifikasi model analisis sebesar 80,6\%. Hasil penelitian menunjukkan bahwa variabel leverage, likuiditas, growth opportunity berpengaruh positif signifikan dan variabel financial distress berpengaruh negatif signifikan, sedangkan variabel fluktuasi nilai tukar berpengaruh tidak signifikan terhadap proses pengambilan keputusan hedging menggunakan instrumen derivatif valuta asing.
\end{abstract}

Kata Kunci: hedging, instrumen derivatif, manajemen risiko, risiko nilai tukar, valuta asing 
PENDAHULUAN

\section{Latar Belakang Masala}

Pada era globalisasi ini banyak negara yang melakukan perdagangan internasional karena globalisasi merupakan salah satu faktor pendorong suatu negara untuk melakukan transaksi perdagangan internasional. Perdagangan internasional adalah kegiatan perekonomian dan perdagangan yang dilakukan oleh penduduk suatu negara dengan penduduk negara lain atas dasar kesepakatan bersama (Feriyanto, 2015). Perdagangan internasional merupakan upaya suatu negara untuk memenuhi kebutuhan masyarakatnya seperti kebutuhan barang dan jasa karena tidak ada satu pun negara di dunia yang dapat memenuhi seluruh kebutuhan masyarakatnya sendiri.

\section{Transaksi}

internasional tidak mudah dilakukan dibandingkan dengan transaksi perdagangan dalam negeri karena transaksi perdagangan internasional melibatkan beberapa negara serta menggunakan beberapa jenis mata uang sehingga membuat transaksi perdagangan internasional lebih rumit dan kompleks. Perbedaan penggunaan mata uang dalam perdagangan internasional dapat menyebabkan terjadinya risiko perubahan nilai tukar mata uang.

Fluktuasi nilai tukar Rupiah terhadap Dollar Amerika pada tahun 20122017 mengalami kenaikan cukup signifikan. Selama tahun 2012-2017, nilai tukar Rupiah mengalami despresiasi tertinggi pada tahun 2015 yang menjadikan nilai tukar Rupiah terhadap mata uang Dollar Amerika mencapai Rp 14.802,-- per Dollar Amerika, hal ini terjadi pada tanggal 29 September 2015.

Fluktuasi nilai mata uang di Indonesia dipengaruhi oleh kebijakankebijakan yang dibuat oleh pemerintah, salah satu kebijakan yang dibuat adalah mengubah sistem nilai tukar di Indonesia. Pada tahun 1997, Indonesia menggunakan sistem nilai tukar tetap dan mengalami perubahan sistem nilai tukar pada pertengahan tahun 1997 yang masih diterapkan hingga saat ini yaitu sistem nilai tukar mengambang bebas. Sistem nilai tukar mengambang bebas merupakan sistem nilai tukar yang nilai tukarnya ditentukan berdasarkan permintaan dan penawaran pasar atas mata uang asing tanpa adanya intervensi dari pemerintah.

Fluktuasi nilai tukar di Indonesia dapat menyebabkan ketidakpastian pembayaran bagi perusahaan yang terlibat dalam transaksi perdagangan internasional. Perusahaan yang melakukan transaksi perdagangan internasional rentan terhadap risiko keuangan karena dalam setiap transaksi menggunakan mata uang asing dan saat terjadi perubahan nilai mata uang asing dapat menimbulkan risiko keuangan bagi perusahaan. Perusahaan harus memiliki strategi untuk mengendalikan risiko tersebut sehingga dapat mengurangi kemungkinan kerugian keuangan.

Dalam mengantisipasi risiko keuangan yang dapat terjadi akibat adanya fluktuasi nilai tukar mata uang maka perusahaan dapat melakukan lindung nilai atau dikenal dengan istilah hedging. Guniarti (2014), hedging merupakan suatu tindakan melindungi perusahaan untuk menghindari atau mengurangi risiko kerugian atas valuta asing sebagai akibat dari terjadinya transaksi bisnis. Hedging atau lindung nilai merupakan suatu bentuk usaha dalam mentransfer risiko kepada pihak lain yang lebih bisa mengelola risiko dengan lebih baik melalui transaksi instrumen keuangan (Hanafi, 2014).

Hedging yang dapat dilakukan untuk melindungi perusahaan dari risiko kerugian nilai mata uang asing salah satunya dengan menggunakan instrumen derivatif valuta asing. Instrumen derivatif dikelompokkan menjadi kontrak future, forward, option dan swap. Menurut Siahaan (2008), semua instrumen derivatif adalah kontrak antara dua pihak pembeli dan penjual yang didalam kontraknya berbagai hal telah disepakati bersama, tetapi realisasinya atau pelaksanaan hal tersebut 
adalah nanti pada tanggal tertentu di masa yang akan datang.

Berbagai penelitian empiris tentang faktor yang mempengaruhi keputusan hedging dengan menggunakan instrumen derivatif sudah banyak dilakukan. Guniarti (2014) menyimpulkan bahwa variabel growth opportunity dan likuiditas tidak berpengaruh signifikan terhadap pengambilan keputusan hedging, sedangkan variabel leverage, firm size dan financial distress berpengaruh signifikan terhadap probabilitas dilakukannya aktivitas hedging.

Penelitian lain yang dilakukan oleh Mediana dan Muharam (2016) mendapatkan hasil bahwa variabel leverage dan cash flow volatility of cash operation to total assets berpengaruh signifikan terhadap probabilitas penggunaan hedging derivatif. Variabel cash ratio, growth opportunity, dan cash flow volatility of operating income berpengaruh positif signifikan, sedangkan variabel current rasio dan financial distress berpengaruh negatif signifikan terhadap probabilitas penggunaan hedging derivatif.

Penelitian yang dilakukan Goklas dan Wahyudi (2016) mendapatkan hasil bahwa variabel likuiditas berpengaruh negatif signifikan terhadap probabilitas kebijakan hedging sedangkan variabel volatilitas arus kas berpengaruh positif signifikan. Variabel kepemilikan manajerial, leverage, growth opportunity, kebijakan dividen serta ukuran perusahaan tidak signifikan berpengaruh terhadap probabilitas kebijakan hedging.

Penelitian Kussulisyanti dan Mahfudz (2016) menyimpulkan bahwa variabel likuiditas, Interest Coverage Ratio, growth opportunity, firm size dan foreign debt berpengaruh signifikan terhadap keputusan hedging. Sedangkan variabel debt to equity ratio dan kepemilikan manajerial berpengaruh tidak signifikan terhadap keputusan hedging.

Dalam penelitian Widyagoca dan Lestari (2016) menyimpulkan bahwa variabel leverage berpengaruh negatif dan signifikan terhadap keputusan hedging. Sedangkan variabel growth opportunities, cash ratio dan current ratio tidak berpengaruh signifikan terhadap keputusan hedging.

\section{Permasalahan}

Berdasarkan perbedaaan hasil penelitian terdahulu (research gap), maka perlu dilakukan pengujian kembali untuk menemukan bukti empiris setiap variabel terhadap pengambilan keputusan hedging dan menambahkan variabel fluktuasi nilai tukar. Variabel ini dinilai dapat mempengaruhi pengambilan keputusan hedging pada perusahaan selain itu belum terdapat penelitian yang menggunakan fluktuasi nilai tukar sebagai salah satu variabel yang mempengaruhi keputusan hedging.

\section{Tujuan}

Berdasarkan rumusan masalah diatas, maka tujuan penelitian ini adalah:

1. Menemukan bukti empiris pengaruh leverage terhadap pengambilan keputusan perusahaan melakukan hedging menggunakan instrumen derivatif valuta asing.

2. Menemukan bukti empiris pengaruh likuiditas terhadap pengambilan keputusan perusahaan melakukan hedging menggunakan instrumen derivatif valuta asing.

3. Menemukan bukti empiris pengaruh growth opportunity terhadap pengambilan keputusan perusahaan melakukan hedging menggunakan instrumen derivatif valuta asing.

4. Menemukan bukti empiris pengaruh financial distress terhadap pengambilan keputusan perusahaan melakukan hedging menggunakan instrumen derivatif valuta asing.

5. Menemukan bukti empiris pengaruh fluktuasi nilai tukar terhadap pengambilan keputusan perusahaan melakukan hedging pada tahun berikutnya dengan menggunakan instrumen derivatif valuta asing. 
TINJAUAN PUSTAKA

Perdagangan Internasional

Perdagangan internasional adalah kegiatan perekonomian yang dilakukan atas kesepakatan bersama antara suatu negara dengan negara lain untuk memenuhi kebutuhan negaranya. Perdagangan internasional berbeda dengan perdagangan dalam negeri, dalam perdagangan internasional terdapat beberapa faktor yang membuat transaksi perdagangan ini sulit salah satu faktornya adalah perbedaan mata uang yang digunakan pada suatu negara.

\section{Risiko Nilai Tukar}

Risiko nilai tukar atau risiko mata uang adalah suatu bentuk risiko yang muncul karena perubahan nilai tukar suatu mata uang terhadap mata uang yang lain. Suatu perusahaan atau pemodal yang memiliki aset atau operasi bisnis lintas negara akan memperoleh risiko jika tidak menerapkan lindung nilai (hedging).

Perubahan nilai tukar mata uang asing dapat berisiko terhadap aliran kas perusahaan dan nilai perusahaan sehingga sangat penting bagi manajer untuk mengetahui seberapa besar kemungkinan risiko perubahan nilai tukar mata uang yang dapat menjadi beban perusahaan sehingga kestabilan arus kas dan nilai perusahaan dapat terjaga (Hanjani, 2011).

Jika kurs mengalami perubahan seperti teori yang dijelaskan diatas maka perubahan tersebut dapat mempengaruhi kondisi perusahaan. Perubahan nilai mata uang asing dapat berdampak kepada suatu perusahaan. Besar atau kecilnya dampak akibat perubahan nilai mata uang tersebut disebut dengan exposure. Menurut Madura (2008), ada tiga penyebab utama terjadinya fluktuasi valuta asing, yaitu transaction exposure, translation exposure dan economic exposure.

\section{Hedging (Lindung Nilai)}

Hedging atau yang disebut juga dengan lindung nilai merupakan suatu usaha yang dilakukan perusahaan untuk melindungi perusahaannya dari eksposur fluktuasi nilai tukar. Aktivitas lindung nilai dilakukan oleh perusahaan yang aktif dalam perdagangan internasional seperti eksporimpor menggunakan satuan nilai tukar mata uang asing tertentu sehingga perusahaan tersebut berpotensi terkena dampak eksposur transaksi, operasional, maupun translasi dalam bisnis (Mediana dan Muharam,2016).

Terdapat berbagai cara yang dapat digunakan untuk melakukan hedging atau lindung nilai guna meminimalisir risiko fluktuasi nilai tukar, salah satu caranya yaitu menggunakan instrumen derivatif. Instrumen derivatif dikelompokkan menjadi empat, yaitu forward contract, future contract, option contract, swap contract (Siahaan,2008:10).

\section{Leverage}

Leverage digunakan untuk menggambarkan kemampuan perusahaan memnuhi seluruh kewajibannya. Leverage dapat diproksikan dengan debt to asset ratio (DAR) yang digunakan untuk mengukur seberapa besar aset perusahaan dibiayai oleh utang atau seberapa besar utang perusahaan dalam memenuhi seluruh kewajibannya (Hery, 2017). DAR dapat dihitung dengan membandingkan total utang dengan total aset.

$$
\text { Debt to Asset Ratio }=\frac{\text { Total Utang }}{\text { Total Aset }}
$$

\section{Likuiditas}

Rasio likuiditas merupakan rasio yang menggambarkan kemampuan perusahaan dalam memenuhi kewajiban jangka pendeknya yang segera jatuh tempo (Hery, 2017). Rasio likuiditas diproksikan dengan current ratio.

Rasio Lancar (Current Ratio), merupakan rasio yang digunakan untuk mengukur kemampuan aset lancar perusahaan untuk memenuhi utang lancarnya. Current ratio merupakan perbandingan antara aset lancar dengan utang lancar.

$$
\text { Current Ratio }=\frac{\text { Aset Lancar }}{\text { Utang Lancar }}
$$

\section{Growth Opportunity}

Growth opportunity merupakan rasio yang mengukur peluang perusahaan mengembangkan usahanya di masa depan (Hidayah dan Prasetiono, 2016). Mengacu pada Zhu (2010), proksi pengukuran 
growth opportunity dalam penelitian ini adalah perbandingan antara MVE (Market Value of Equity) dan BVE (Book Value of Equity).

$$
\text { Growth Opportunity }=\frac{\mathrm{MVE}}{\mathrm{BVE}}
$$

Keterangan:

$$
\begin{aligned}
& \text { MVE }=\frac{\text { EAT }}{\text { EPS }} \times \text { harga penutupan } \\
& \text { BVE }=\text { Total asset }- \text { total liabilitas }
\end{aligned}
$$

\section{Financial Distress}

Financial distress merupakan suatu proses menurunnya posisi keuangan perusahaan yang dapat menyebabkan kesulitan keuangan dan berujung pada kebangkrutan. Financial distress dapat diukur menggunakan $Z$ Score (Altman,1968).

$$
Z=1,2 X_{1}+1,4 X_{2}+3,3 X_{3}+0,6 X_{4}+1,0 X_{5}
$$

Keterangan:

$\mathrm{X}_{1}=\frac{\text { Working Capital }}{\text { Total Assets }}$

$\mathrm{X}_{2}=\frac{\text { Retained Earnings }}{\text { Total Assets }}$

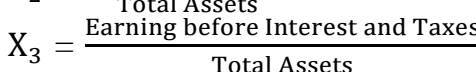

$\mathrm{X}_{4}=\frac{\text { Market Value of Equity }}{\text { Total Liabilities }}$

$\mathrm{X}_{5}=\frac{\text { Sales }}{\text { Total Assets }}$

$\mathrm{Z}=$ Overall Index or Score

$$
\begin{array}{ll}
\multicolumn{1}{c}{\text { Score: }} & \\
\mathrm{Z}>2,99 & \text { Safe Zone (tidak bangkrut) } \\
1,81<\mathrm{Z}<2,99 & \text { Grey Zone (daerah kelabu) } \\
\mathrm{Z}<1,81 & \text { Distress Zone (bangkrut) }
\end{array}
$$

\section{Fluktuasi Nilai Tukar}

Fluktuasi nilai tukar merupakan perubahan nilai tukar mata uang terhadap mata uang asing lainnya. Tingkat fluktuasi nilai tukar dapat dilihat dengan membandingkan nilai tukar tahun sebelumnya dengan tahun sekarang.

$$
\text { FNT }=\frac{\text { Nilai Tukar } \mathrm{t}-\text { Nilai Tukar } \mathrm{t}-1}{\text { Nilai Tukar } \mathrm{t}-1} \times 100 \%
$$

Keterangan:

Nilai tukar $\mathrm{t}$ : nilai tukar tahun sekarang

Nilai tukar t-1 : nilai tukar tahun sebelumnya

\section{Kerangka Penelitian}

Gambar 1 Kerangka Penelitian

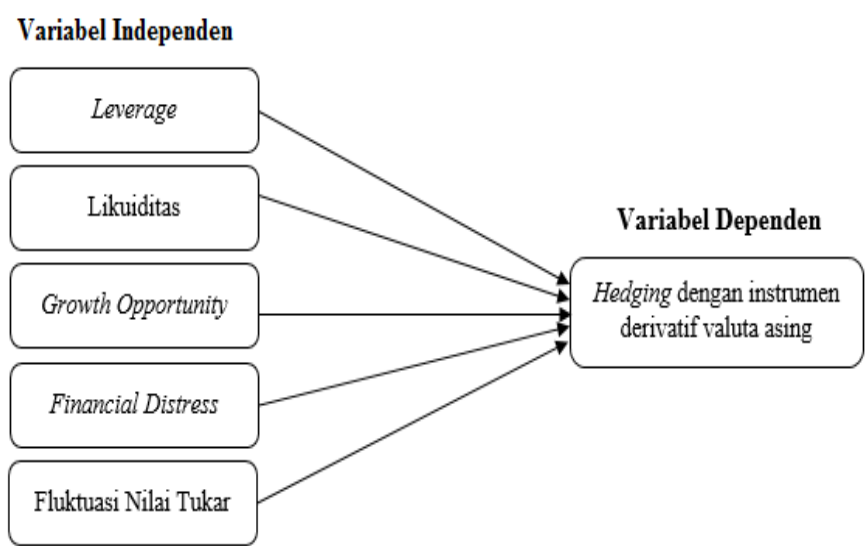

\section{Hipotesis Penelitian}

$\mathrm{H}_{1}$ : Leverage berpengaruh positif terhadap pengambilan keputusan hedging derivatif.

$\mathrm{H}_{2}$ : Likuiditas berpengaruh negatif terhadap pengambilan keputusan hedging derivatif.

$\mathrm{H}_{3}$ : Growth opportunity berpengaruh positif terhadap pengambilan keputusan hedging derivatif.

$\mathrm{H}_{4}$ : Financial distress berpengaruh negatif terhadap pengambilan keputusan hedging derivatif.

$\mathrm{H}_{5}$ : Fluktuasi nilai tukar tahun sebelumnya berpengaruh positif terhadap pengambilan keputusan hedging derivatif.

\section{METODOLOGI}

Jenis penelitian ini adalah penelitian kuantitatif deskriptif. Penelitian kuantitatif deskriptif merupakan suatu jenis penelitian yang bertujuan untuk mendeskripsikan jawaban penelitian secara luas dan mendalam terhadap suatu permasalahan yang diteliti dengan menggunakan pendekatan kuantitatif.

Jenis data yang digunakan dalam penelitian ini adalah data sekunder berupa laporan keuangan tahunan auditan pada perusahaan yang terdaftar di BEI periode 2013-2017. Sumber data dalam penelitian ini diperoleh dari website Bursa Efek Indonesia serta website perusahaan yang diteliti.

Populasi yang digunakan dalam penelitian ini adalah perusahaan non keuangan yang terdaftar di Bursa Efek Indonesia (BEI) selama periode 2013-2017 yang berjumlah 462 perusahaan. Metode pengambilan sampel dalam penelitian ini menggunakan metode purposive sampling 
yaitu pemilihan sampel dengan tujuan dan kriteria tertentu.

Model penelitian yang digunakan dalam penelitian ini adalah analisis regresi logistik. Menurut Ghozali (2011), regresi logistik digunakan untuk menguji apakah probabilitas terjadinya variabel terikat atau dependen variable dapat diprediksi dengan variabel bebasnya atau independent variable. Penelitian ini dilakukan dengan menggunakan metode regresi logistik yang dibantu dengan menggunakan software SPSS versi 24.

Metode analisis yang digunakan, yaitu statistik deskriptif untuk memberikan deskripsi dari setiap variabel penelitian yang dapat dilihat dari karakteristik data, yaitu mean, minimum, maximum, dan standard deviation. Uji kelayakan model, untuk menilai kelayakan keseluruhan model dapat dilakukan dengan melakukan beberapa test statistik. Analisis uji kelayakan model dalam regresi logistik dibagi menjadi 3 jenis, yaitu uji overall model fit, Cox \& Snell $R$ square dan Nagelkerke $R$ square dan Hosmer and Lemeshow's goodness of fit test.

Selanjutnya, tabel klasifikasi untuk menghitung estimasi nilai benar dan salah. Kolom tabel klasifikasi merupakan dua nilai prediksi dari variabel dependen sedangkan pada baris tabel menunjukkan nilai observasi yang sesungguhnya dari variabel dependen.

Terakhir, uji hipotesis dilakukan untuk menguji koefisien regresi yang didapat signifikan atau tidak signifikan. Uji hipotesis ini juga dilakukan untuk melihat pengaruh variabel independen terhadap variabel dependen.

\section{HASIL DAN PEMBAHASAN}

Hasil seleksi sampel yang telah dilakukan dengan metode purposive sampling, maka diperoleh sampel sebanyak 35 perusahaan yang terdiri dari 16 perusahaan yang melakukan hedging dengan menggunakan instrumen derivatif dan 19 perusahaan yang melakukan hedging tidak dengan menggunakan instrumen derivatif selama periode penelitian yaitu tahun 2013-2017. Dengan menggunakan pengamatan selama 5 tahun, maka jumlah sampel dalam penelitian ini sebanyak 175 (35 x 5) sampel penelitian. Perusahaan yang menjadi sampel penelitian harus menyajikan data laporan keuangan tahunan audit secara lengkap selama periode 2013-2017.

\section{Deskripsi Analisis Hedging}

Tabel 1 Hasil Deskripsi Observasi

\begin{tabular}{|l|l|r|r|r|r|}
\hline \multicolumn{2}{|c|}{} & Frequency & Percent & $\begin{array}{c}\text { Valid } \\
\text { Percent }\end{array}$ & $\begin{array}{c}\text { Cumulative } \\
\text { Percent }\end{array}$ \\
\hline \multirow{7}{*}{ Valid } & $\begin{array}{l}\text { Tidak Hedging } \\
\text { Derivatif }\end{array}$ & 95 & 54,3 & 54,3 & 54,3 \\
\cline { 2 - 6 } & $\begin{array}{l}\text { Hedging } \\
\text { Derivatif }\end{array}$ & 80 & 45,7 & 45,7 & 100,0 \\
\cline { 2 - 6 } & Total & 175 & 100,0 & 100,0 & \\
\hline
\end{tabular}

Sumber: Output SPSS versi 24, 2018

Berdasarkan data pada Tabel 1, diperoleh jumlah keseluruhan data observasi yang tidak melakukan aktivitas hedging dengan menggunakan instrumen derivatif sebanyak 95 data atau 54,3\% dari keseluruhan data observasi sedangkan 80 atau $45,7 \%$ data observasi lainnya dinyatakan melakukan hedging dengan menggunakan instrumen derivatif selama tahun pengamatan, yaitu tahun 2013 sampai 2017.

\section{Statistik Deskriptif}

Berikut merupakan hasil statistik deskriptif pada kedua variabel dalam penelitian ini:

Tabel 2 Hasil Uji Statistik Deskriptif

\begin{tabular}{|l|r|r|r|r|r|}
\hline & $\mathrm{N}$ & Minimum & Maximum & Mean & $\begin{array}{c}\text { Std. } \\
\text { Deviation }\end{array}$ \\
\hline LEV & 175 & 0,119 & 0,881 & 0,52977 & 0,183783 \\
\hline LIQ & 175 & 0,404 & 7,632 & 1,81765 & 1,503615 \\
\hline GO & 175 & 0,120 & 45,465 & 2,96199 & 5,628310 \\
\hline FD & 175 & 0,079 & 48,152 & 4,16510 & 6,372687 \\
\hline FNT & 175 & $-0,635$ & 13,654 & 7,55240 & 6,259829 \\
\hline $\begin{array}{l}\text { Valid N } \\
\text { (listwise) }\end{array}$ & 175 & & & & \\
Sumber: Output SPSS versi 24, 2018
\end{tabular}

Tabel 2 menunjukkan bahwa jumlah data yang diuji untuk masing-masing variabel sebanyak 175 data observasi. Berdasarkan hasil analisis deskriptif tersebut dapat dilihat jika variabel leverage (LEV) memiliki nilai minimum sebesar 0.119 dan nilai maksimum sebesar 0,881 yang dapat diartikan jika tingkat leverage perusahaan ada pada tingkat 0,119 sampai 
dengan 0,881 dengan nilai rata-rata 0,530 dan standar deviasi 0,184 .

Pada hasil analisis variabel likuiditas (LIQ) diperoleh nilai minumim likuiditas sebesar 0,404 dan nilai maksimumnya sebesar 7,632 serta nilai rata-rata tingkat likuiditas perusahaan sebesar 1,818 dengan nilai standar deviasi sebesar 1,504. Oleh karena itu, dapat disimpulkan bahwa tingkat likuiditas perusahaan berada pada nilai 0,404 sampai dengan 7,632.

Variabel growth opportunity (GO) memiliki nilai minimum sebesar 0,120 dan nilai maksimum sebesar 45,465 , sedangkan nilai rata-rata sebesar 2,961 dan standar deviasi sebesar 5,628. Hasil analisis tersebut menunjukkan bahwa tingkat growth opportunity pada perusahaan berada pada nilai 0,120 sampai dengan 45,465.

Berdasarkan hasil analisis deskriptif diatas, tingkat financial distress pada perusahaan yang diteliti memiliki nilai minimum sebesar 0,079 dan nilai maksimum sebesar 48,152. Nilai rata-rata dari tingkat financial distress perusahaan sebesar 4,165 dengan standar deviasi sebesar 6,373.

Variabel fluktuasi nilai nukar memiliki nilai minimum sebesar -0,635 dan nilai maksimum fluktuasi nilai tukar sebesar 13,654. Nilai rata-rata fluktuasi nilai tukar berdasarkan hasil analisis deskriptif sebesar 7,552 dengan nilai standar deviasi sebesar 6,260.

\section{Uji Kelayakan Model}

1. Uji Overall Model Fit

Berikut ini hasil analisis uji Overall Model Fit untuk melihat hasil analisis 2 Log Likelihood (block number $=0$ ) dimana model hanya menggunakan konstanta saja.

Tabel 3 Hasil Uji Overall Model Fit (Block Number $=0$ )

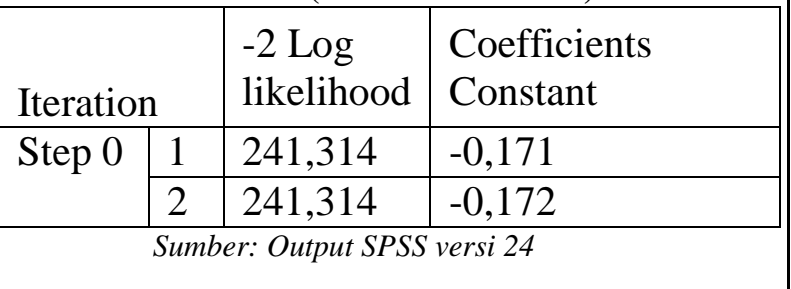

2. Cox and Snell $R$ Square dan Nagelkerke $R$ Square

Tabel 4 Hasil Uji Model Summary (Block Number = 1)

\begin{tabular}{|l|l|l|l|}
\hline Step & $\begin{array}{l}-2 \text { Log } \\
\text { likelihood }\end{array}$ & $\begin{array}{l}\text { Cox \& } \\
\text { Snell R } \\
\text { Square }\end{array}$ & $\begin{array}{l}\text { Nagelkerke } \\
\text { R Square }\end{array}$ \\
\hline 1 & $167,003^{\text {a }}$ & 0,346 & 0,462 \\
\hline \multicolumn{3}{|c|}{ Sumber: Output SPSS versi 24}
\end{tabular}

Berdasarkan Tabel 3 dan Tabel 4, nilai hasil analisis -2 Log Likelihood pada awal model (block number $=0$ ) yang hanya menggunakan konstanta sebesar 241,314 sedangkan nilai -2 Log Likelihood (block number $=1$ ) yang menggunakan konstanta dan variabel independennya mengalami penurunan menjadi 167,003 yang artinya -2 Log Likelihood awal (block number $=0)>$ -2 Log Likelihood (block number $=1$ ) sehingga dapat dikatakan bahwa model regresi layak digunakan.

Pada Tabel 4 didapati nilai Cox \& Snell $R$ Square dan Nagelkerke $R$ Square sebesar 0,346 dan 0,462 yang menunjukkan variabilitas variabel dependen dapat dijelaskan oleh variabilitas variabel independent sebesar 46,2\% dan 53,8\% lainnya dari variabilitas pada variabel dependen dijelaskan oleh faktor-faktor lain yang di luar dari variabel independen yang digunakan.

3. Hosmer and Lemeshow's Goodness of Fit Test

Berikut ini adalah hasil analisis Goodness of Fit Test dengan menggunakan Hosmer and Lemeshow untuk menguji hipotesis nol apakah data empiris cocok dengan model sehingga model dapat dikatakan fit atau layak dipakai dan tidak ada perbedaan antara model dengan data.

Tabel 5 Hasil Uji Goodness of Fit Test

\begin{tabular}{|l|l|l|l|}
\hline Step & Chi-square & Df & Sig. \\
\hline 1 & 8,143 & 8 & 0,420 \\
\hline \multicolumn{4}{|c|}{ Sumber: Output SPSS versi 24} \\
Uji goodness of fit test dilakukan
\end{tabular}

untuk menguji hipotesis nol apakah data empiris cocok atau sesuai dengan model fit data yang diukur menggunakan chi square pada hasil uji. 
Pada tabel 5 didapati nilai chi square sebesar 8,143 dengan nilai probabilitas signifikannya sebesar 0,420 . Hasil ini menunjukkan bahwa $\mathrm{H}_{0}$ diterima karena nilai probabilitas signifikannya lebih besar dari 0,05 yaitu sebesar 0,420. Dengan diterimanya $\mathrm{H}_{0}$ berarti model regresi layak dipakai karena tidak ada ketidakcocokan antara klasifikasi yang diprediksi dengan klasifikasi yang diamati.

\section{Uji Klasifikasi Model}

Tabel 6 Hasil Uji Klasifikasi Model Analisis

\begin{tabular}{|c|c|c|c|c|c|}
\hline \multirow{3}{*}{\multicolumn{3}{|c|}{ Observed }} & \multicolumn{3}{|c|}{ Predicted } \\
\hline & & & \multicolumn{2}{|c|}{ Aktivitas Hedging } & \multirow{3}{*}{$\begin{array}{r}\begin{array}{c}\text { Percentage } \\
\text { Correct }\end{array} \\
89,5\end{array}$} \\
\hline & & & Tidak Hedoino & Hedoing & \\
\hline \multirow{3}{*}{$\begin{array}{l}\text { Step } \\
1\end{array}$} & \multirow{2}{*}{$\begin{array}{l}\text { Aktivitas } \\
\text { Hedging }\end{array}$} & $\begin{array}{l}\text { Tidak Hedging } \\
\text { Derivatif }\end{array}$ & 85 & 10 & \\
\hline & & $\begin{array}{l}\text { Hedging } \\
\text { Derivatif }\end{array}$ & 24 & 56 & 70,0 \\
\hline & \multicolumn{2}{|c|}{ Overall Percentage } & & & 80,6 \\
\hline
\end{tabular}

Berdasarkan tabel klasifikasi model diketahui bahwa prediksi observasi yang tidak melakukan aktivitas hedging derivatif sebanyak 95, sedangkan hasil observasinya didapati sebanyak 85 dengan tingkat ketepatan klasifikasinya sebesar $89,5 \%$. Ketepatan prediksi observasi yang melakukan aktivitas hedging derivatif sebanyak 80 , sedangkan hasil observasinya hanya sebanyak 56 dengan tingkat ketepatan klasifikasinya sebesar $70 \%$. Secara keseluruhan ketepatan klasifikasi model ini sebesar $80,6 \%$ yang berarti hasil penelitian cukup baik karena mendekati ketepatan $100 \%$.

\section{Uji Koefisiensi Regresi}

Tabel 7 Hasil Uji Koefisiensi Regresi Logistik

\begin{tabular}{|l|l|r|r|r|r|r|r|}
\hline \multicolumn{2}{|c|}{} & \multicolumn{1}{|c|}{ B } & S.E. & \multicolumn{1}{|c|}{ Wald } & df & Sig. & Exp(B) \\
\hline \multirow{4}{*}{ Step $1^{\mathrm{a}}$} & LEV & 4,849 & 1,799 & 7,269 & 1 & 0,007 & 127,625 \\
\cline { 2 - 8 } & LIQ & 0,578 & 0,200 & 8,379 & 1 & 0,004 & 1,783 \\
\cline { 2 - 8 } & GO & 1,524 & 0,286 & 28,317 & 1 & 0,000 & 4,589 \\
\cline { 2 - 8 } & FD & $-0,302$ & 0,135 & 5,034 & 1 & 0,025 & 0,739 \\
\cline { 2 - 8 } & FNT & $-0,039$ & 0,031 & 1,637 & 1 & 0,201 & 0,961 \\
\cline { 2 - 8 } & Constant & $-5,355$ & 1,335 & 16,091 & 1 & 0,000 & 0,005 \\
\hline
\end{tabular}

Berikut ini hasil uji koefisiensi regresi logistik dimana hasil uji ini digunakan untuk melihat pengaruh dari variabel independen terhadap variabel dependen dan juga untuk menentukan hasil uji hipotesis penelitian.

Pengujian koefisien regresi untuk menguji seberapa besar pengaruh variabel independen yang dimasukkan dalam model terhadap variabel dependennya. Berikut ini merupakan persamaan regresi logistik berdasarkan dari hasil analisis yang dilakukan:

$$
\begin{aligned}
& \operatorname{Ln} \frac{p}{1-p}=-5,355+4,849 \mathrm{LEV}+0,578 \mathrm{LIQ} \\
& \stackrel{+}{+} 1,524 \mathrm{GO}-0,302 \mathrm{FD}-0,039 \mathrm{FNT}
\end{aligned}
$$

Berdasarkan persamaan regresi logistik diatas dapat dilihat bahwa varibel leverage, likuiditas dan growth opportunity berpengaruh positif sehingga semakin tinggi nilai variabel independen tersebut dapat meningkatkan probabilitas pengambilan keputusan hedging. Pada variabel independen lainnya yaitu, financial distress dan fluktuasi nilai tukar berpengaruh negatif maka semakin tinggi nilai variabel independen tersebut dapat membuat menurunkan tingkat probabilitas pengambilan keputusan hedging.

\section{Pengaruh Leverage terhadap Pengambilan Keputusan Hedging Derivatif}

Hasil uji regresi logistik menunjukkan bahwa variabel leverage memiliki nilai koefisien regresi sebesar 4,849 dengan nilai probabilitas sebesar 0,007 yang lebih kecil daripada 0,05 (alpha) sehingga dapat disimpulkan bahwa leverage perusahaan memiliki pengaruh positif signifikan terhadap pengambilan keputusan hedging dengan menggunakan instrumen derivatif valuta asing.

Hasil penelitian tersebut menunjukkan kesesuaian antara hipotesis dengan hasil penelitian yang sudah dilakukan bahwa semakin meningkatnya nilai leverage perusahaan maka akan meningkatkan probabilitas pengambilan keputusan hedging derivatif. Sebaliknya, semakin rendah nilai leverage perusahaan maka semakin rendah probabilitas 
pengambilan keputusan hedging derivatif. Hasil penelitian ini sesuai dengan dengan hasil penelitian yang dilakukan oleh Guniarti (2014) bahwa variabel leverage berpengaruh positif terhadap pengambilan keputusan hedging.

Rasio leverage yang tinggi menandakan bahwa perusahaan memiliki utang yang tinggi yang dapat meningkatkan profitabilitas perusahaannya. Perusahaan yang melakukan eksposur transaksi atau mempunyai utang dengan menggunakan mata uang asing sangat rentan terhadap fluktuasi nilai tukar mata uang. Semakin besar utang perusahaan dalam mata uang asing maka semakin besar juga risiko yang dihadapi oleh perusahaan. Risiko tersebut dapat berupa risiko gagal bayar serta kesulitan keuangan yang dapat menimbulkan kebangkrutan pada perusahaan. Untuk menghindari risiko gagal bayar dan kesulitan keuangan perusahaan perlu melakukan strategi manajemen risiko yaitu lindung nilai (hedging) dengan menggunakan instrumen derivatif valuta asing.

\section{Pengaruh Likuiditas terhadap Pengambilan Keputusan Hedging Derivatif}

Hasil uji regresi logistik menunjukkan bahwa variabel likuiditas memiliki nilai koefisien regresi sebesar 0,578 dengan nilai probabilitas sebesar 0,004 yang lebih kecil daripada 0,05 (alpha) sehingga dapat disimpulkan bahwa likuiditas berpengaruh positif dan signifikan terhadap pengambilan keputusan hedging dengan menggunakan instrumen derivatif valuta asing. Hasil penelitian tersebut menyatakan bahwa $\mathrm{H}_{2}$ ditolak. Oleh karena itu, hasil dari penelitian ini menyatakan bahwa likuiditas perusahaan berpengaruh positif terhadap pengambilan keputusan hedging derivatif. Hasil penelitian ini sesuai dengan penelitian yang dilakukan oleh Widyagoca dan Lestari (2016).

Rasio likuiditas digunakan untuk mengukur kemampuan perusahaan dalam memenuhi kewajiban jangka pendeknya, maka semakin tinggi likuiditas perusahaan, semakin likuid pula perusahaan tersebut. Perusahaan yang likuid juga menandakan bahwa perusahaan tersebut memiliki jumlah aset lancar yang besar dibandingkan utang lancarnya. Jika aset lancar tersebut didominasi dengan kas yang terlalu besar, maka manajemen perusahaan belum mengoptimalkan penggunaan kasnya dengan baik.

Pada saat perusahaan memiliki jumlah kas yang terlalu besar, maka perusahaan perlu melakukan hedging agar terhindar dari risiko kerugian. Oleh karena itu, perusahaan non keuangan yang memiliki tingkat likuiditas yang besar cenderung melakukan hedging instrumen derivatif valuta asing untuk menghindari risiko tersebut.

\section{Pengaruh Growth Opportunity terhadap Pengambilan Keputusan Hedging Derivatif} Hasil uji regresi logistik menunjukkan bahwa variabel growth opportunity memiliki nilai koefisien regresi sebesar 1,524 dengan nilai probabilitas sebesar 0,000 yang lebih kecil daripada 0,05 (alpha). Hasil tersebut menunjukkan bahwa growth opportunity memiliki tanda koefisien regresi yang positif dan nilai signifikansi yang lebih kecil dari 0,05 sehingga dapat disimpulkan bahwa growth opportunity berpengaruh positif signifikan terhadap pengambilan keputusan hedging dengan menggunakan instrumen derivatif valuta asing. Hal ini menyatakan bahwa $\mathrm{H}_{3}$ diterima. Hasil penelitian ini sesuai dengan dengan hasil penelitian yang dilakukan oleh Guniarti (2014), Kussulistyanti dan Mahfudz (2016) serta Mediana dan Muharam (2016).

Bagi perusahaan yang memiliki tingkat growth opportunity yang tinggi cenderung akan melakukan hedging untuk melindungi perusahaannya dari risiko fluktuasi nilai tukar dan juga kebangkrutan. Dapat disimpulkan bahwa semakin tinggi tingkat growth opportunity perusahaan maka semakin tinggi probabilitas 
perusahaan untuk melakukan pengambilan keputusan hedging.

\section{Pengaruh Financial Distress terhadap Pengambilan Keputusan Hedging Derivatif} Hasil uji regresi logistik menunjukkan bahwa variabel financial distress yang diproksikan menggunakan $Z$ Score memiliki nilai koefisien regresi sebesar -0,302 dengan nilai probabilitas sebesar 0,025 yang lebih kecil daripada 0,05 (alpha). Hasil tersebut menunjukkan bahwa financial distress memiliki tanda koefisien regresi yang negatif dan nilai signifikansi yang lebih kecil dari 0,05 sehingga dapat disimpulkan bahwa financial distress berpengaruh negatif signifikan terhadap pengambilan keputusan hedging dengan menggunakan instrumen derivatif valuta asing. Hal ini menyatakan bahwa $\mathrm{H}_{4}$ diterima. Hasil penelitian ini sesuai dengan dengan hasil penelitian yang dilakukan oleh Guniarti (2014) serta Mediana dan Muharam (2016) bahwa variabel financial distress berpengaruh negatif terhadap pengambilan keputusan hedging.

Hasil penelitian tersebut menunjukkan kesesuaian antara hipotesis dengan hasil penelitian yang sudah dilakukan bahwa semakin meningkatnya nilai financial distress yang dilihat dari hasil perhitungan $Z$ Score yang tinggi mengindikasikan bahwa perusahaan berada pada zona aman dari kebangkrutan sehingga hal tersebut menurunkan probabilitas penggunaan hedging pada perusahaan. Sebaliknya, jika perusahaan memiliki hasil perhitungan $Z$ Score yang rendah mengindikasikan bahwa perusahaan berada pada zona distress atau bangkrut sehingga perusahaan perlu meningkatkan probabilitas penggunaan hedging.

Perusahaan yang melakukan ekposur transaksi dengan mata uang asing akan sangan rentan terhadap anacaman kebangkrutan terlebih jika perusahaan tersebut sudah dikategorikan dalam zona distress berdasarkan hasil perhitungan $Z$ Score. Selain itu, perusahaan yang memiliki utang dalam mata uang asing dan sudah dikategorikan sudah mengalami kesulitan keuangan juga harus lebih memperhatikan kondisi keuangannya.

\section{Pengaruh Fluktuasi Nilai Tukar terhadap Pengambilan Keputusan Hedging Derivatif} Hasil uji regresi logistik menunjukkan bahwa variabel fluktuasi nilai tukar memiliki nilai koefisien regresi sebesar -0,039 dengan nilai probabilitas sebesar 0,201 yang lebih besar daripada 0,05 (alpha). Hasil tersebut menunjukkan bahwa fluktuasi nilai tukar memiliki tanda koefisien regresi yang negatif dan nilai signifikansi yang lebih besar dari 0,05 sehingga dapat disimpulkan bahwa fluktuasi nilai tukar tidak signifikan berpengaruh terhadap pengambilan keputusan hedging dengan menggunakan instrumen derivatif valuta asing. Hal ini menyatakan bahwa $\mathrm{H}_{5}$ ditolak.

Hasil penelitian tersebut menunjukkan ketidaksesuaian antara hipotesis dengan hasil penelitian yang sudah dilakukan bahwa semakin tinggi fluktuasi nilai tukar mata uang maka akan meningkatkan probabilitas pengambilan keputusan hedging derivatif. Fluktuasi nilai tukar yang semakin tinggi menandakan bahwa semakin besar risiko nilai tukar yang dihadapi oleh perusahaan tetapi risiko tersebut dapat dihindari dengan penggunaan hedging.

Berdasarkan uraian diatas, maka dapat disimpulkan bahwa fluktuasi nilai tukar tidak mempengaruhi probabilitas pengambilan keputusan hedging karena adanya sistem nilai tukar mengambang yang membuat fluktuasi nilai tukar sangat tinggi dan penggunaan hedging dinilai tidak efektif untuk menghindari perusahaan dari kerugian akibat fluktuasi tersebut.

Hasil yang tidak signifikan pada hasil penelitian variabel fluktuasi nilai tukar dapat disebabkan karena periode waktu penelitian yang singkat sehingga data yang terkumpul belum mewakili keadaan riilnya dan juga fenomena fluktuasi yang tidak terlalu signifikan selama periode penelitian. 


\section{KESIMPULAN}

1. Variabel leverage yang diproksikan menggunakan debt to asset (DAR) memiliki pengaruh positif dan signifikan terhadap pengambilan keputusan hedging menggunakan instrumen derivatif valuta asing.

2. Variabel likuiditas yang diproksikan menggunakan current ratio memiliki pengaruh positif dan signifikan terhadap pengambilan keputusan hedging menggunakan instrumen derivatif valuta asing.

3. Variabel growth opportunity memiliki pengaruh positif dan signifikan terhadap pengambilan keputusan hedging menggunakan instrumen derivatif valuta asing.

4. Variabel financial distress memiliki pengaruh negatif dan signifikan terhadap pengambilan keputusan hedging menggunakan instrumen derivatif valuta asing.

5. Variabel fluktuasi nilai tukar tidak signifikan berpengaruh terhadap pengambilan keputusan hedging menggunakan instrumen derivatif valuta asing.

\section{SARAN}

1. Nilai $R$ Square Nagelkerke pada penelitian ini hanya sebesar 46,2\%, dimana terdapat $53,8 \%$ lainnya yang dapat dijelaskan menggunakan faktorfaktor lain diluar lima variable yang digunakan dalam penelitian ini. Pada penelitian selanjutnya disarankan untuk menambahkan variable lain agar dapat menghasilkan hasil penelitian yang lebih baik.

2. Penelitian selanjutnya diharapkan untuk untuk menguji ulang variabel fluktuasi nilai tukar dengan menggunakan periode pengamatan yang lebih panjang. Hasil penelitian tersebut diharapkan memberikan hasil yang lebih akurat dan menggambarkan keadaan yang lebih riil.

3. Bagi perusahaan yang memiliki tingkat financial distress rendah, disarankan untuk tidak melakukan pinjaman modal eksternal. Jika perusahaan ingin tetap melakukan pinjam tersebut, maka perusahaan harus melakukan hedging menggunakan instrumen derivatif valuta asing agar dapat terhindar dari risiko fluktuasi nilai tukar.

4. Penelitian selanjutnya disarankan untuk menambahkan variabel kontrol,seperti variabel firm size dan foreign debt agar dapat memberikan hasil penelitian yang lebih baik dan akurat.

\section{DAFTAR PUSTAKA}

Augusty, F. (2006). Metode Penelitian Manajemen: Pedoman Penelitian untuk Skripsi, Tesis dan Disertai Ilmu Manajemen. Semarang: Universitas Diponegoro.

Ball, D. G. (2014). Bisnis Internasional Buku 2 Edisi 12. Jakarta: Salemba Empat.

Bank Indonesia. (2018, Mei 30). Kalkulator Kurs. Diambil kembali dari Website Bank Indonesia: https://www.bi.go.id/id/moneter/kalk ulator-kurs/Default.aspx

Bursa Efek Indonesia. (2018, Maret 8). Fact Book IDX. Diambil kembali dari Website Bursa Efek Indonesia: http://www.idx.co.id/datapasar/laporan-statistik/fact-book/

Bursa Efek Indonesia. (2018, Mei). Laporan Keuangan dan Tahunan. Diambil kembali dari Website Bursa Efek Indonesia: http://web.idx.id/idid/beranda/perusahaantercatat/lapora nkeuangandantahunan.aspx

Eiteman, D. S. (2010). Manajemen Keuangan Multinasional Jilid II Edisi Kesebelas. Jakarta: Penerbit Erlangga.

Feriyanto, A. (2015). Perdagangan Internasional: Kupas Tuntas Prosedur Ekspor Impor. Yogyakarta: Mediatera.

Ghozali, I. (2011). Aplikasi Analisis Multivariate dengan Program IBM SPSS 19 Edisi 5. Semarang: Badan Penerbit Universitas Diponegoro. 
Ghozali, I. (2018). Aplikasi Analisis Multivariate dengan Program IBM SPSS 25 Edisi 9. Semarang: Badan Penerbit Universitas Diponegoro.

Guniarti, F. (2014). Faktor-faktor yang Mempengarhi Aktivitas Hedging dengan Instrumen Derivatif Valuta Asing. Jurnal Dinamika Manajemen Vol.5, No.1, pp:64-79.

Hanafi, M. M. (2014). Manajemen Risiko. Yogyakarta: UPP STIM YKPN.

Hanjani, A. (2011). Faktor-faktor yang Mempengaruhi Penggunaan Hedging pada Perusahaan Non-Financial Indonesia yang Terdaftar pada Bursa Efek Indonesia Tahun 2003-2009. Depok: Program Studi Manajemen Fakultas Ekonomi Universitas Indonesia.

Hery. (2015). Analisis Kinerja Manajemen. Jakarta: Grasindo.

Lestari, I. G. (2016). Pengaruh Leverage, Growth Opportunities, dan Liquidity Terhadap Pengambilan Keputusan Hedging PT Indosat Tbk. E-Jurnal Manajemen Unud Vol.5, No.2, pp: 1282-1308.

Madura, J. (2008). International Corporate Finance 8th Edition. USA: Thomson South-Western Company.

Madura, J. (2012). International Corporate Finance 11th Edition. USA: Thomson South-Western Company.

Mahfudz, M. J. (2016). Analisis Faktorfaktor yang Mempengaruhi Keputusan Hedging dengan Derivatif Valuta Asing (Studi pada Perusahaan Non-Finansial yang Terdaftar di Bursa Efek Indonesia Periode Tahun 2011-2014). Diponegoro Journal of Management Vol.5, No.3, pp1-14.

Muharam, I. M. (2016). Analisis Faktorfaktor yang Mempengaruhi Pengambilan Keputusan Lindung Nilai (Hedging) Menggunakan Instrumen Derivatif (Studi Kasus pada Perusahaan Manufaktur dan Perusahaan Energi dan Sumber Daya Mineral yang Terdaftar di BEI Periode 2010-2014) . Semarang:
Diponegoro Journal of Management Vol.5, No.2, pp: 1-14.

Nur, M. (2013). Analisis Kebijakan Lindung Nilai dan Pengaruhnya terhadap Nilai Perusahaan : Studi Empiris pada Bursa Efek Indonesia. Skripsi. Sekolah Pascasarjana Institut Pertanian Bogor.

Prasetiono, N. H. (2016). Faktor Penent Perusahaan Melakukan Pengambilan Keputusan Hedging pada Derivatif Valuta Asing (Studi Kasus pada Perusahaan Manufaktur yang Terdaftar di BEI Periode 2011-2014). Diponegoro Journal of Management Vol.5, No.3, pp: 1-13.

Siahaan, H. (2008). Seluk-Beluk Perdagangan Instrumen Derivatif. Jakarta: PT Elex Media Komputindo.

Supriyono, R. (2016). Manajemen Risiko. Yogyakarta: Gadjah Mada University Press.

Wahyudi, F. G. (2016). Kebijakan Hedging dan Faktor-faktor yang Mempengaruhinya (Studi Empiris pada Perusahaan Non Finansial yang Terdaftar di BEI Periode 2012-2014). Diponegoro Journal of Management Vol.5, No.4, pp:1-14.

Yusgiantoro, P. (2004). Manajemen Keuangan Internasional: Teori dan Praktik. Jakarta: Penerbitan Fakultas Ekonomi Universitas Indonesia.

Zhu, M. R. (2010). Corporate Hedging, Financial Distress and Product Market Competition. Working Paper. Austin: University of Texas 
